\title{
Engineered Micro-Objects as Scaffolding Elements in Cellular Building Blocks for Bottom-Up Tissue Engineering Approaches
}

Citation for published version (APA):

Leferink, A., Schipper, D., Arts, E., Vrij, E., Rivron, N., Karperien, M., Mittmann, K., van Blitterswijk, C., Moroni, L., \& Truckenmueller, R. (2014). Engineered Micro-Objects as Scaffolding Elements in Cellular Building Blocks for Bottom-Up Tissue Engineering Approaches. Advanced Materials, 26(16), 2592-2599. https://doi.org/10.1002/adma.201304539

Document status and date:

Published: 01/04/2014

DOI:

10.1002/adma.201304539

Document Version:

Publisher's PDF, also known as Version of record

Document license:

Taverne

Please check the document version of this publication:

- A submitted manuscript is the version of the article upon submission and before peer-review. There can be important differences between the submitted version and the official published version of record.

People interested in the research are advised to contact the author for the final version of the publication, or visit the DOI to the publisher's website.

- The final author version and the galley proof are versions of the publication after peer review.

- The final published version features the final layout of the paper including the volume, issue and page numbers.

Link to publication

\footnotetext{
General rights rights.

- You may freely distribute the URL identifying the publication in the public portal. please follow below link for the End User Agreement:

www.umlib.nl/taverne-license

Take down policy

If you believe that this document breaches copyright please contact us at:

repository@maastrichtuniversity.nl

providing details and we will investigate your claim.
}

Copyright and moral rights for the publications made accessible in the public portal are retained by the authors and/or other copyright owners and it is a condition of accessing publications that users recognise and abide by the legal requirements associated with these

- Users may download and print one copy of any publication from the public portal for the purpose of private study or research.

- You may not further distribute the material or use it for any profit-making activity or commercial gain

If the publication is distributed under the terms of Article 25fa of the Dutch Copyright Act, indicated by the "Taverne" license above, 


\title{
Engineered Micro-Objects as Scaffolding Elements in Cellular Building Blocks for Bottom-Up Tissue Engineering Approaches
}

\author{
A. Leferink, D. Schipper, E. Arts, E. Vrij, N. Rivron, M. Karperien, K. Mittmann, \\ C. van Blitterswijk, L. Moroni,* and R. Truckenmüller*
}

In tissue engineering (TE) and regenerative medicine, directing or modulating cell behavior is known to be vital for the development of constructs to replace lost or damaged tissue. ${ }^{[1]}$ In this study, we introduce a material-based bottom-up approach which allows to build up millimeter-sized geometrically shaped viable tissue constructs. With this new biofabrication platform, we show that it is possible to influence cell-material interactions and improve the distribution of viable cells throughout engineered tissues. By tailoring the physical and chemical properties of cell-adherent micro-objects functioning as scaffolding elements, the compaction and morphology of the formed tissue constructs can be modulated.

Conventional TE approaches are based on combining autologous cells with a synthetic or biological material which provides a mechanically stable 3D environment to culture a substitute graft in vitro suited for implantation. ${ }^{[2]}$ Therefore, tissue engineers and material scientists have been developing multitude of scaffold materials, with distinct geometries and physicochemical properties, and 3D culture methods. A great benefit of utilizing 3D scaffolds is the opportunity to create constructs of clinically relevant sizes and shapes. However, several hurdles with respect to cell culture on these scaffolds need to be overcome. These include inhomogeneous cell distribution, necrotic cores due to nutrient diffusion limitations and lack of vascularization, restricted remodelling capacity, and limited material-based control of cell fate due to limited accessibility of the scaffolds for surface modification or functionalization in 3D. ${ }^{[3]}$ These drawbacks to a bigger extent origin from the static nature of the scaffolds' architectures.

Recently, bottom-up TE has been introduced to overcome these limitations. Bottom-up approaches have the potential

\footnotetext{
A. Leferink, D. Schipper, E. Arts, E. Vrij, Dr. N. Rivron Prof. M. Karperien, Prof. C. van Blitterswijk, Dr. L. Moroni, Dr. R. Truckenmüller Department of Tissue Regeneration MIRA Institute for Biomedical Technology and Technical Medicine University of Twente 7522 NB Enschede, The Netherlands E-mail: I.moroni@utwente.nl; r.k.truckenmuller@utwente.nl Prof. K. Mittmann

Fachbereich Physikalische Technik Münster University of Applied Sciences 48565 Steinfurt, Germany
}

DOI: 10.1002/adma.201304539 to construct tissues with defined properties including spatial and temporal control at cellular level. ${ }^{[4]}$ Assembling individual building blocks allows for the fabrication of large complex tissue constructs. Currently, there are several bottom-up approaches under investigation from which the state-of-theart was reviewed recently. ${ }^{[4 \mathrm{~b}, 5]}$ A first approach is based on scaffold-free cultures where cells are aggregated into 3D tissue constructs. ${ }^{[5 a, 6]}$ Baraniak and McDevitt reported that murine mesenchymal stromal cells (MSCs) cultured as spheroids in suspension without the use of a scaffold as a cell carrier preserve their multilineage potential better than murine MSCs cultured as a monolayer. In addition, our group showed that the fate of human MSCs (hMSCs) within large aggregates is determined by collectively generated actomyosin tension depending on the position of the cells within the aggregates. These scaffold-free aggregates tend to compact and round up, also when one tries to control the aggregate shape by culturing in correspondingly shaped wells. This compaction in scaffoldfree approaches is not hindered by a material acting as a spacer, resulting in high numbers of cells required to obtain clinically relevant sized tissue constructs.

A second approach is based on gel-like materials and can overcome this problem of compaction by allowing the cells to reside in an extra cellular matrix (ECM) mimicking environment. ${ }^{[7]}$ The use of hydrogels has shown a high potential in injectable systems to reduce in vivo the invasiveness of surgical procedures and to allow in vitro for controlled assembly achieving complex tissues. However, the limitation of hydrogels is their limited load bearing capacity which makes them a less suitable material, for example, in hard tissue repair. ${ }^{[8]}$ Moreover, hydrogels only allow diffusion of nutrients and gases, soluble factors and waste products which limits the size of constructs that can retain cells viability. This diffusion limit often results in the cells mainly residing on the extremes of the hydrogel where the access to oxygen is better, therewith decreasing the homogeneity of the cellular distribution. ${ }^{[9]}$ A third drawback of using hydrogels is related to their processing. Most cell-laden hydrogels opted for use in TE approaches are processed by crosslinking of cellcontaining precursors with the aid of potentially toxic or denaturizing crosslinking agents. This process is known to create or represent an unfavorable, chemically reactive (free radicals) and toxic microenvironment for the cells also including harmful ionizing UV-light and or elevated temperatures. ${ }^{[10]}$

In contrast to encapsulating cells in hydrogel structures, we propose a material-based bottom-up approach in which we let 

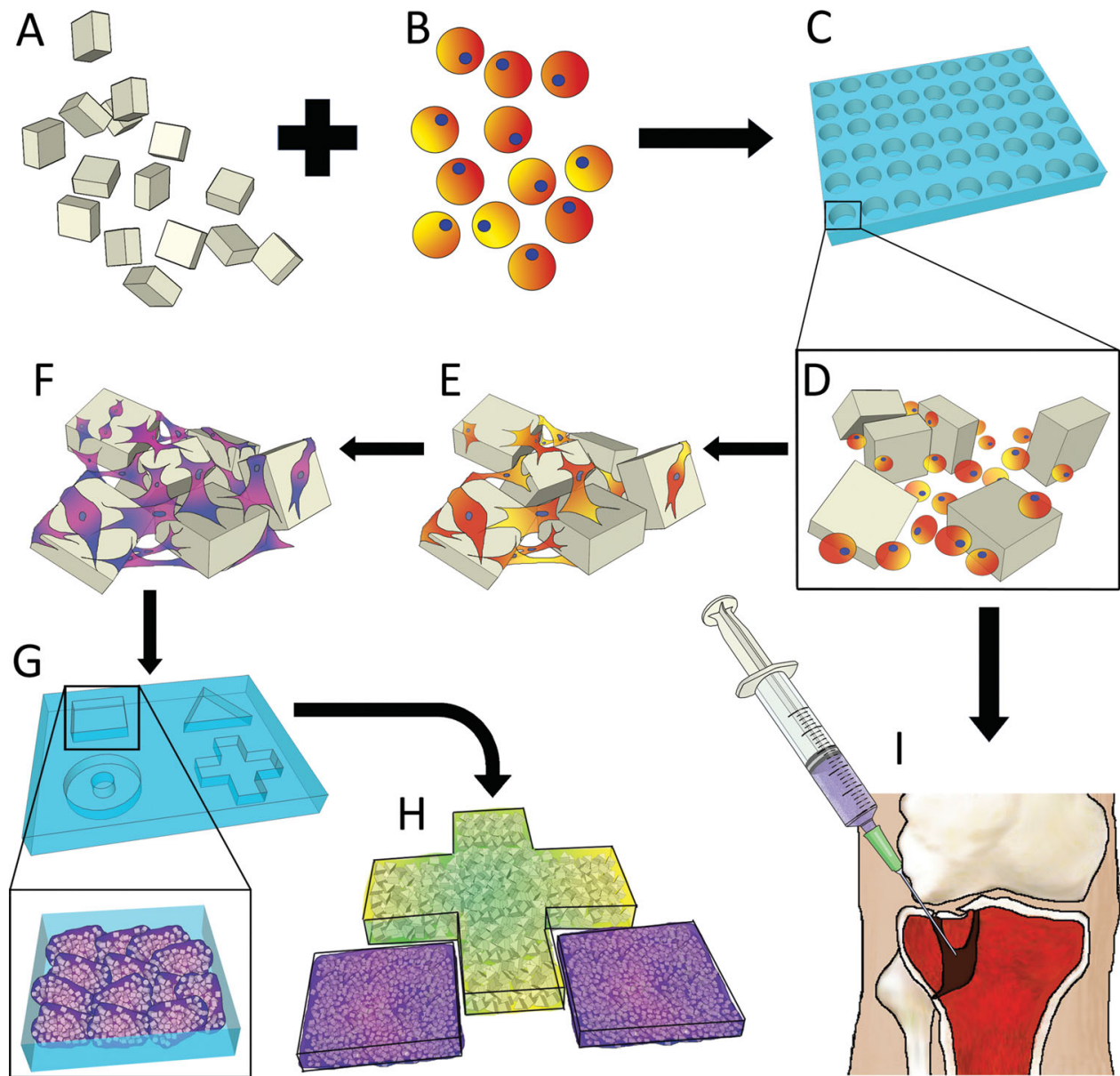

Scheme 1. Schematic representation of bottom-up TE approach with microfabricated solid objects. (A) Micro-objects and (B) cells are cultured in (C) arrays of micro-wells to pre-aggregate. (D) Micro-objects directly after seeding. (E, F) Aggregate formation and cell fate (represented by a color change) can be influenced by the geometrical, mechanical, physical and chemical surface and bulk properties of the objects. (G) After pre-aggregation, multiple micro-aggregates can be transferred and pooled into geometrically defined wells to fuse into larger sized tissue constructs. (H) Subsequently, constructs of different shapes and from various cell types can be combined to form controlled complex tissues. (I) A suspension of micro-objects and cells can be applied directly into a defect site where the objects act as a filler and as mechanical support, and ideally comprises instructive or inductive properties for the cells to grow and differentiate.

the cells self-assemble together with instructive engineered solid micro-objects into (shaped) aggregates which then can be fused into bigger geometrical units. We hypothesize that our method allows for the formation of complex 3D constructs by hierarchical assemblies of multiple cell and object types. Cell seeding on these individual micro-objects showed to retain cell viability and considerably improve cellular distribution compared to conventional 3D scaffolds. Moreover, we also show that the modulation of the object's properties such as their shape, size and wettability, in combination with variations of cell culture conditions and cell-to-object ratios, tailors the circularity, branching and compaction of the cell-driven assembly. This conveys to the new biofabrication platform proposed here an unprecedented degree of freedom in engineering instructive cell-material interactions, at the same time solving the drawbacks of current top-down and bottom-up approaches. The micro-objects in our strategy can function as carriers for cell delivery or as cell-assembled scaffolds for tissue constructs of clinically relevant sizes as shown in Scheme 1. Other applications could be found in those fields working with complex 3D tissues such as stem cell research, cancer research, developmental biology, bioartificial organs, pharmaceutical drug testing or toxicity testing.

As in the first instance we want to show the concept of our bottom-up approach, the micro-objects were simply fabricated by direct lithography from the photocurable epoxy-resin SU-8 (Microchem) just as a model material. This material is not used to replace tissues, but it has a multiple-documented biocompatibility and is used in various biomedical microdevices, also in vivo. ${ }^{[11]}$ We proved however that similar micro-objects in principle can be also fabricated from an established thermoplastic and photoinitiator-free bio(degradable) polymer such as poly-DL-lactic acid by an advanced process based on thermal micro- or nanoimprint lithography on a water-soluble sacrifical layer. The SU-8 objects were released from the wafer on which they were fabricated by dissolving a sacrificial layer in this case from OmniCoat (Microchem) in N-methyl-2-pyrrolidone (NMP) (Figure S1 in the Supporting information). To increase 


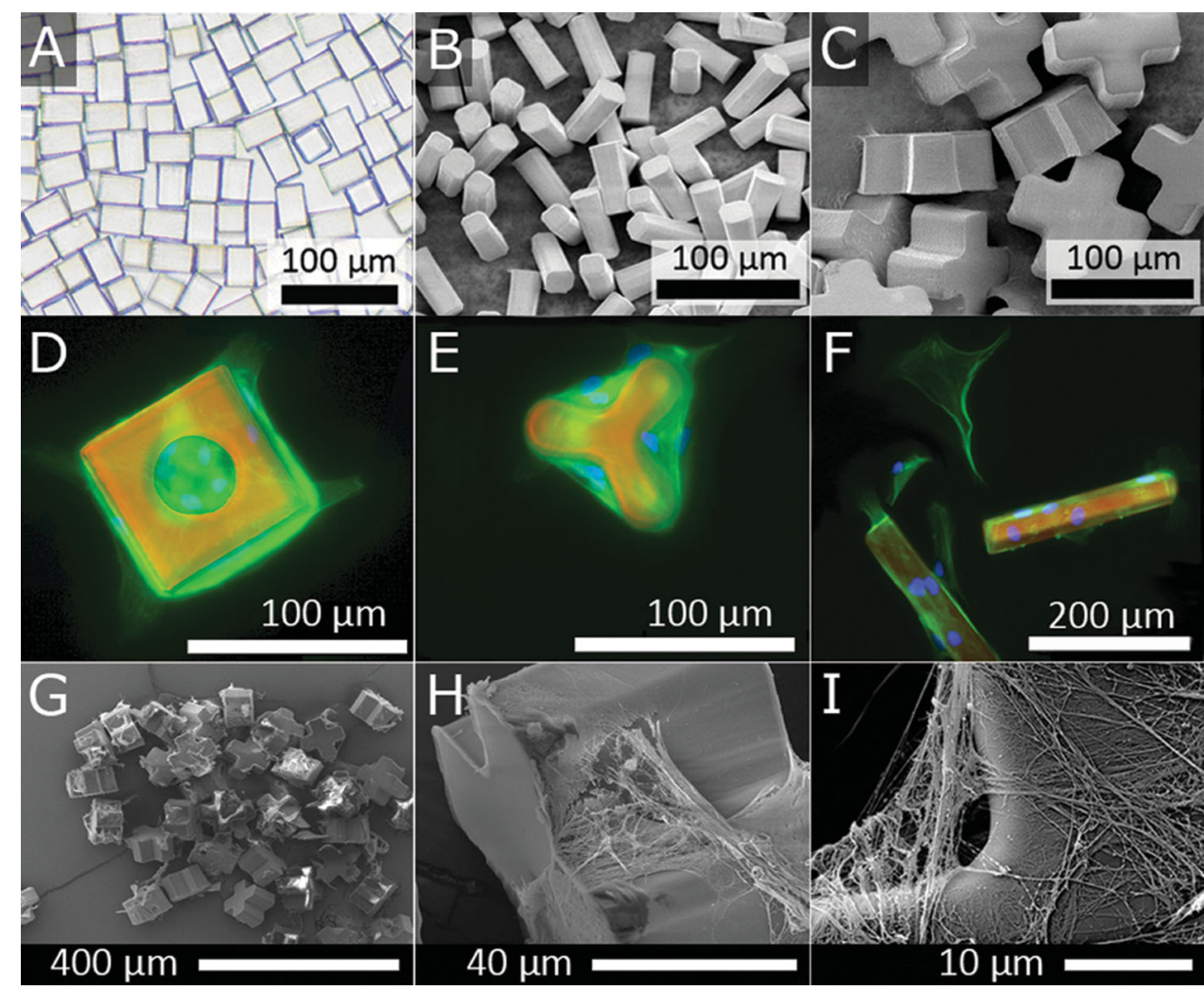

Figure 1. (A) Small-sized $\left(20 \times 20 \times 40 \mu \mathrm{m}^{3}\right)$ micro-objects are successfully released from the wafer by dissolving the OmniCoat sacrificial layer after fabrication. (B, C) Scanning electron microscopy (SEM) images show that objects with distinct geometries were successfully fabricated and released from the substrate wafer. (D-F) When culturing iMSCs on oxygen-treated SU-8 micro-objects, a DAPI (nuclei, blue) and Phalloidin (cytoskeleton, green) staining shows that multiple cells adhere to single objects (adapted from bright field image, red), thereby even bridging between the extremities or residing in a hole of an object. (G-I) SEM images show that hMSCs adhere to multiple cross-shaped objects. The cells bridge between the objects and produce a high amount of ECM-like material.

the hydrophilicity of the objects, still on the wafer, they were treated in an oxygen plasma. To render some objects even more hydrophilic, a chemical etch in sulfuric acid was carried out. The wettability of the material upon the oxygen and sulfuric acid treatment was determined by contact angle measurements and protein adsorption tests (fluorescein-labeled bovine serum albumin, BSA) (Table S1 in the Supporting information).

After successful release from the wafer, a suspension of micro-objects (Figure 1A) can be handled like a cell suspension, meaning that objects can be centrifuged, counted or even introduced in a flow cytometer. Prior to cell culture, the objects were washed extensively in deionized (DI-)water and subsequently in $70 \%$ ethanol to remove traces of NMP and to sterilize, respectively. The objects have a defined shape which stays intact throughout the releasing and sterilization processes (Figure 1B and $\mathrm{C}$ ). For cell culture experiments, a murine myoblast cell line (C2C12), a murine pre-chondrogenic cell line (ATDC5), immortalized MSCs (iMSCs), ${ }^{[12]}$ and hMSCs were used.

After combining a relative low number of oxygen-plasmatreated micro-objects with iMSCs or $\mathrm{C} 2 \mathrm{C} 12$ cells on a nontissue-culture-treated polystyrene plate, cells were found to attach to the SU-8 objects within 24 hours of culture (Figure 1D-F). DAPI/Phalloidin staining shows the nuclei and cytoskeletons of multiple iMSCs adhering to individual objects.
Cells were able to bridge a hole in an object (Figure 1D) or bridge between the extremities of an object (Figure 1E). A similar behavior was found for $\mathrm{C} 2 \mathrm{C} 12$ cells. Figure $1 \mathrm{G}$ and $\mathrm{H}$ show that the iMSCs adhere to the objects and spread over the objects surface. At higher magnification (Figure 1I), it can be clearly seen that the cells produce ECM on the material surface, which suggests that the cells are highly metabolically active. These results show that the observed cell-material interactions are promising for further studies on the applicability of the objects as potential cell supporting structures. Therefore, the experiments were upscaled to higher number of cells and objects per well to study cell-material interactions at larger scale.

The number of objects that were assembled into aggregates and the compaction of these aggregates were monitored for two sizes of cube-shaped objects (medium (M): $40 \times 40 \times 40 \mu \mathrm{m}^{3}$, large (L): $80 \times 80 \times 40 \mu^{3}$ ) (medium cube-shaped objects in Figure 1A) and one size of large cross-shaped objects $(90 \times 90 \times$ $40 \mathrm{\mu m}^{3}$; Figure $1 \mathrm{C}$ ) at several timepoints. The volume of a crossshaped object in these experiments corresponded to the volume of a large cube. Figure 2 shows how fast the cells and objects form aggregates. By changing the cell-to-structure ratio, the culture conditions, the wettability, and the size and shape of the objects, the density of the formed aggregates can be controlled. Figure S2 shows the quantification of the aggregation behavior 


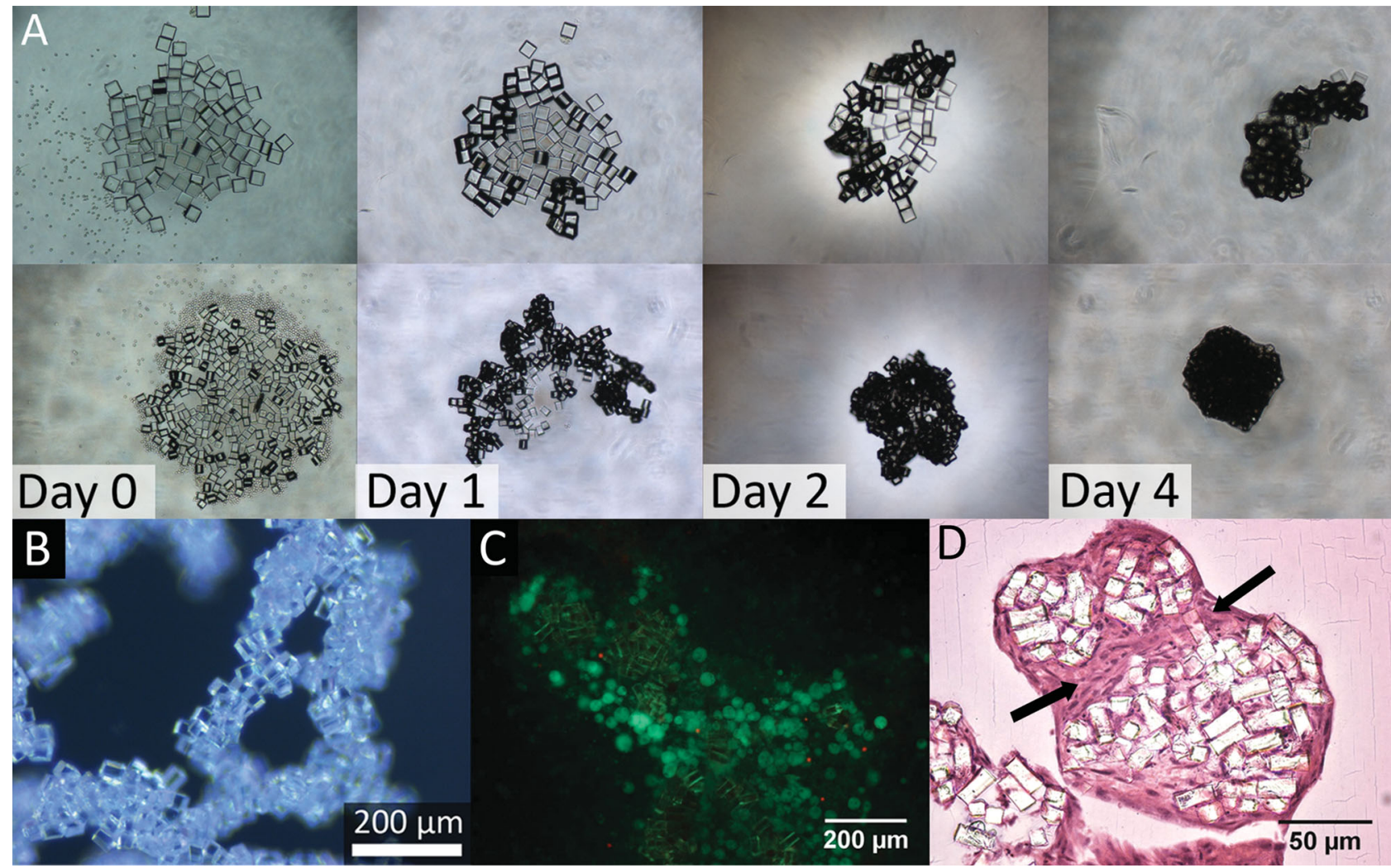

Figure 2. (A) Two time sequences of iMSCs cultured with cube-shaped objects of different sizes (first row: large $=80 \times 80 \times 40 \mu \mathrm{m}^{3}$; second row: medium $=40 \times 40 \times 40 \mu \mathrm{m}^{3}$ ) on a hemispherical layer of $1 \%$ agarose are shown. The sum of the objects' volumes was adjusted to be the same for both sequences. It can be seen that the smaller objects show comparatively high compaction within 4 days, resulting in a round aggregate, whereas the larger objects inhibit the remodelling of the aggregate, resulting in a compact, but not complete circular aggregate. (B) After 4 days of culturing, a low number of cells combined with large micro-objects $\left(80 \times 80 \times 40 \mu \mathrm{m}^{3}\right)$ on a flat layer of $1 \%$ agarose, a branched open network of cells and objects is found. It can be clearly seen that the geometry of the aggregate is very distinct from the aggregates formed on a hemispherical layer of $1 \%$ agarose. (C) A calcein/etidium homodimer staining shows that most cells are alive (green) after 7 days of culture, just a few $(<5 \%)$ dead cells (red) are found for hMSCs cultured with multiple object types. (D) Hematoxilin and eosin staining confirms a homogenous cell distribution within aggregates and shows bridging of the cells between the aggregates (indicated by arrows).

of the objects and the cells by determining the percentage of the total number of objects which was incorporated in an aggregate. When the objects were incubated in cell culture medium without the presence of cells, no aggregation was observed, even after several weeks. The relative number of aggregated objects was lower on sulfuric-acid-treated objects than on oxygenplasma-treated structures when a low number of cells $(500$ cells per well) was seeded. Furthermore it was found that the relative number of aggregated objects is lower for $\mathrm{C} 2 \mathrm{C} 12$ cells compared to iMSCs. iMSCs are known to spread in culture, whereas C2C12 cells show a smaller, spindle-like morphology. This difference in morphology could lead to iMSCs being able to cover more object surface area and can therewith also spread over multiple objects.

Significant differences were also found in the shape of the formed aggregates described by the circularity, which is given by a function of the perimeter $\mathrm{P}$ and the area A of a projection of the aggregate (Equation S1 in Supporting information). A higher aspect ratio (variance in the diameter of the aggregate) or degree of branching of the aggregate results in a lower circularity. A significant difference $(\mathrm{p}<0.001)$ in circularity depending on the cell type was observed in five out of six conditions where iMSCs showed a higher circularity than $\mathrm{C} 2 \mathrm{C} 12$ cells (Figure S3). Only for sulfuric-acid-treated crosses, no significant difference was found. This difference in aggregation behavior between cell types could, just like the relative number of objects in an aggregate, be explained by the morphology of the cells. Due to the spread morphology of iMSCs compared to C2C12 cells, actomyosin forces could be carried out on more objects per cell in the case of iMSCs. iMSCs were also found to produce a lot of ECM which also could have promoted fast aggregation and remodelling. With respect to the influence of the treatment of the objects, four out of six conditions showed a significantly higher circularity for oxygen-plasma-treated objects compared to sulfuric-acid-treated objects. This result suggests that oxygen plasma treatment not only results in a more suitable hydrophilicity for cell adherence but also allows cells to a higher extent to spread and adhere to multiple objects which induces remodelling and compaction of the aggregate possibly by actomyosin forces. Other parameters that could have an influence on circularity are the shape and size of the objects. ${ }^{[8]}$ With respect to the shape of the structures, cubes 
were expected to show higher circularity than crosses due to their more compact geometry. However, differences were found only for sulfuric-acid-treated objects seeded with iMSCs where large cubes showed a significantly higher circularity than the large cross-shaped objects. Structure size was also expected to play a role in the compactness of the aggregate, where large micro-objects were expected to result in less circular aggregates than smaller ones. Though, for this parameter, no significant differences were found in any of the conditions. This could be caused by the fact that the size and shape of the objects was only altered in 2D, whereas the third dimension (the thickness of the SU-8 layer in the fabrication process) stayed constant at $40 \mu \mathrm{m}$.

When a low number of cells is combined with large microobjects on a flat layer of $1 \%$ agarose (Figure $2 \mathrm{~B}$ ), the geometry of the aggregate was very distinct from the aggregates formed on a hemispherical layer of $1 \%$ agarose (Figure 2A). This suggests that the compactness and circularity of the aggregates is not solely cell-guided, but can also be modulated by the culture conditions (Figure S4A-D). Other potential approaches to control the density and complexity of the aggregates could for example be the design of objects having a high aspect ratio or asymmetry, which could inhibit the compaction sterically, or by partial functionalizion of the objects to create amphiphilic elements or to introduce a so-called 'DNA glue' for directing the mesoscale assembly. ${ }^{[13]}$

To investigate whether these aggregates can be monitored with respect to cell viability, morphology and tissue growth, and to increase the clinical relevance, further experiments were carried out using oxygen-plasma-treated objects combined with hMSCs. Life/dead staining showed a high cell viability (>95\%) after 4 days (Figure 2C) of culture which was confirmed by flow cytometry on various shapes of SU-8 objects (Figure S5). It was also found that the cells distribute homogeneously throughout the aggregate and can fuse several small aggregates into a larger sized aggregate (Figure 2D and S6). The viability of large aggregates of objects and cells (initially 10,000 objects and 50,000 hMSCs) and of aggregates consisting of hMSCs only was assessed after 11 days of culture and compared (Figure S7).

The positive results on cell proliferation found by DNA quantification (Figure S8) and the high cell viability shown in Figure 2C, S5 and S7, make the micro-objects promising candidates as 3D cell carriers for upscaling expansion cultures. Furthermore, the objects have large potential as filler material since the volume of the obtained tissue constructs showed to be much larger compared to cell-only cultures without microobjects (Figure S9).

To further show that the cells continuously remodel the aggregates, three spherical aggregates were brought into one well after 7 days of culture. The aggregates clearly merged into one larger-sized aggregate within 4 days (Figure 3A) as already found by histological analysis (Figure 2D). To study migration of cells from one aggregate to another after fusion, cells were pre-stained with fluorescent dyes (Di-I and Di-O). The fluorescently labeled cells were seeded separately with the micro-objects to form red or green stained aggregates. Cells did not only bridge the aggregates, but migrated from one aggregate to another upon fusion (Figure S10A and B). As a proof of concept for engineered larger-sized tissue constructs with controlled geometry, chondrogenic ATDC5 cells and objects were pre-aggregated into spherical aggregates in $400 \mu \mathrm{m}$ diameter microwells (Figure 3B). After 4 days of pre-aggregation, the micro-aggregates were flushed out of the microwells (Figure 3C, Video S1B) and successfully fused into larger geometric aggregates in millimetre-sized wells (Figure 3D). After 10 days of allowing the aggregates to fuse into millimetre-sized toroids, these toroids were stacked to form a stable tracheashaped tubular structure within 5 days after stacking (Figure 3E and $\mathrm{F}$ ).

Histological analysis of this toroidal tissue construct again showed high number of cells homogeneously distributed between the objects without indications of necrosis (Figure S11). One can imagine that this same approach could be applied for the development of vessel-like constructs when using vascular endothelial cells or for defect-shaped bone fillers when using osteoblast precursors, among other applications.

To overcome the limitations of cell-based or gel-based bottom-up approaches with respect to mechanical stability, the micro-objects could function as an enforcing material introducing more mechanical stability in for example cellular aggregates or in hydrogel approaches (Supporting data Table S2 and S3) ${ }^{[14]}$. To show the potential of our objects to be used in an injectable system as presented in Scheme 1, several injectability tests were performed. The following conditions were assessed, hMSCs with objects in culture medium, cell-object-aggregates in culture medium and cell-object-aggregates in an alginate solution which was crosslinked directly after extrusion (Supplementary Video S1-S3). The viability of the injected cells was assessed qualitatively 6 hours after extrusion through a $18 \mathrm{G}$ needle by a live/dead staining (Figure S7 E and F).

To overcome possible nutrient deficiency when upscaling the size of the assembled tissue constructs towards the sub-cm or cm-range, the objects could for example be designed with a high asymmetry or high aspect ratio features which could sterically limit compaction introducing cavities and channels through which medium can be perfused. Another approach is to already enable vascularisation in the early stage of culture in vitro by culturing the cells and objects on top of a vascular bed as presented by Sekine et al. ${ }^{[15]}$

In summary, this study showed how shape, size and wettability of engineered micro-objects can play an important role when cells are allowed to assemble with these objects. A major difference between our approach and cell-only or hydrogelbased bottom-up approaches can be found in the role of the cells in assembling macro-sized tissue constructs. ${ }^{[6 c, 7 a, 13,16]}$ The approach presented here allows the cells to bind to a substrate material allowing cell-cell contact which could be beneficial for certain cell-types and applications. Our approach shows how relatively low number of cells are required to obtain large mmsized viable tissue constructs compared to cell-only approaches. Moreover, the cells are able to actively assemble and remodel these aggregates, whereas in hydrogel based bottom-up TE other approaches such as DNA-glue have to be introduced to direct mesoscale assemblies. By modulating cell attachment sites on the micro-objects, higher control on aggregate parameters such as aggregation rate and compactness could be achieved.

Further development of the bottom-up approach presented in this study will be focused on characterization of cell-material 


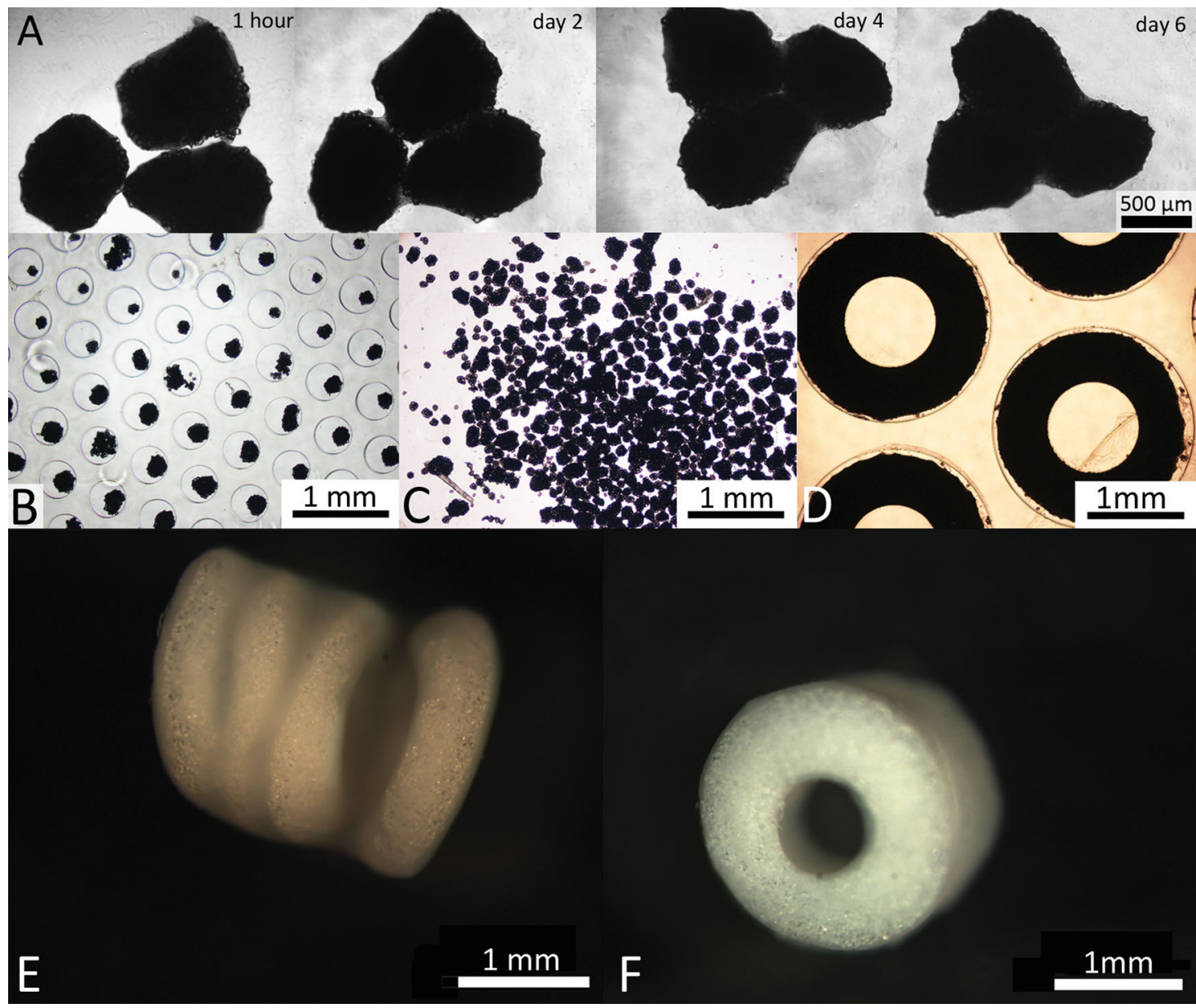

Figure 3. (A) After 7 days of aggregation on a hemispherical layer of $1 \%$ agarose, three aggregates were brought into close vicinity into one well. Within 4 days, the aggregates fused due to cells bridging and migrating from one aggregate to another. (B) Cells and objects are pre-aggregated in agarose microwells with a diameter of $400 \mu \mathrm{m}$. (C) After 4 days, stable and compact aggregates can be flushed out of the wells and transferred to larger-sized, geometrically shaped agarose wells. (D) Toroidal tissue constructs are formed within 4 days of culture which can subsequently be stacked on a needle to form (E, F) stable tubular structures within another 4 days.

interactions in combination with micro-objects fabricated from biocompatible, implantable materials such as polylactide, polytrimethylene carbonate or copolymers of polyethylene oxide terephthalate and polybutylene terephthalate. Subsequently, a major step towards the design of a system in which cell fate and tissue shape as well as tissue complexity can be controlled will be the investigation of the influence of - among others - object size, shape, stiffness and surface chemistry or topography on cellular phenotype.

Ultimately, this approach could not only be used as a tool to engineer complex 3D tissues of clinically relevant size, but it could also find its application in the clinic for example as injectable system, ${ }^{[8]}$ or in the pharmaceutical industry as a 3D model to study tissue pathology and discover potentially new drugs.

\section{Experimental Section}

Micro-Object Fabrication: The OmniCoat sacrificial layer was spincoated on a 4 " silicon wafer followed by a $44 \pm 2 \mu \mathrm{m}$ layer of SU-8.
Subsequently, the bilayered film was soft-baked using a programmed hotplate $\left(50{ }^{\circ} \mathrm{C}\right.$ for $10 \mathrm{~min}, 65^{\circ} \mathrm{C}$ for $10 \mathrm{~min}, 95^{\circ} \mathrm{C}$ for $20 \mathrm{~min}$, cooling down back to $25{ }^{\circ} \mathrm{C}$ ). The micro-objects were obtained by exposing the photoresist (soft contact mode $30 \mu \mathrm{m}, 24 \mathrm{~s}, \mathrm{Hg}, 12 \mathrm{~mW} \mathrm{~cm}{ }^{-2}$, EVG 620 mask aligner, EV Group, Austria). To harden the photoresist, a post exposure bake was performed using a programmed hotplate $\left(50{ }^{\circ} \mathrm{C}\right.$ for $5 \mathrm{~min}, 65{ }^{\circ} \mathrm{C}$ for $5 \mathrm{~min}, 80^{\circ} \mathrm{C}$ for $10 \mathrm{~min}$, slow cool down to $25{ }^{\circ} \mathrm{C}$ ). The unexposed photoresist was removed by spray development for 6 min (Resist Edgebead Remover 600, RER 600 , MicroChem). To increase the hydrophilicity of the structures, they were treated in an oxygen plasma $\left(50 \% \mathrm{O}_{2}\right)$ for $3 \mathrm{~min}$ at $600 \mathrm{~W}$ (TePla 300E plasma processor). The micro-objects were released from the wafer by dissolving the sacrificial layer with $\mathrm{N}$-methyl-2-pyrrolidone (NMP). To render in some cases the objects even more hydrophilic, a chemical etch in $95 \%$ sulfuric acid was carried out at $80{ }^{\circ} \mathrm{C}$ for $10 \mathrm{~s}$. The hydrophilicity of the material upon the oxygen plasma and sulfuric acid treatment was determined by performing contact angle measurements and protein adsorption tests (fluorescein-labeled BSA, Sigma). Prior to cell culture experiments, the objects were sterilized by immersion in $70 \%$ ethanol twice for $30 \mathrm{~min}$, followed by washing three times in phosphate-buffered saline (PBS). Subsequently, the objects were incubated in $10 \%$ fetal bovine serum (FBS, Lonza) containing culture media for at least $24 \mathrm{~h}$. 
Cell Culture: hMSC isolation and expansion was performed as previously described on human bone marrow aspirates obtained from donors after written informed consent ${ }^{[17]}$ iMSCs represent an immortalized clone retrieved after transducing hMSCs with the gene for the catalytic subunit of human telomerase (hTERT) (iMSCs, courtesy of Ola Myklebost, University of Oslo, Norway). hMSCs and iMSCs were cultured in a monolayer in proliferation medium consisting of alpha minimum essential medium ( $\alpha$-MEM, Gibco) supplemented with L-glutamine $\left(2 \mathrm{~mm}\right.$, Gibco), penicillin (100 $\mathrm{U} \mathrm{ml}^{-1}$, Gibco) and streptomycin $\left(100 \mathrm{mg} \mathrm{ml}^{-1}\right.$, Gibco), FBS (10\% ( $\left.\mathrm{w} \mathrm{v}^{-1}\right)$, Lonza), basic fibroblast growth factor (1 $\mathrm{ng} \mathrm{ml}^{-1}, \mathrm{bFGF}$, Instruchemie) and ascorbic acid (0.2 mM, Sigma). C2C12 and ADTC5 cells were cultured in a monolayer in Dulbecco's Modified Eagle medium (DMEM, Gibco) supplemented with penicillin $\left(100 \mathrm{U} \mathrm{ml}^{-1}\right.$, Gibco) and streptomycin (100 mg ml $\left.\mathrm{m}^{-1}, \mathrm{Gibco}\right)$, and 10\% FBS $\left(\left(\mathrm{w} \mathrm{v}^{-1}\right)\right.$, Lonza) for $\mathrm{C} 2 \mathrm{C} 12$ cells and $5 \%$ FBS for ADTC5 cells. Standard culturing conditions were $37^{\circ} \mathrm{C}$ with a humidified $5 \% \mathrm{CO}_{2} / 95 \%$ air atmosphere. Media were renewed every second (ATDC5) or third day (all other cell types). Cells were detached using trypsin $\left(0.25 \%\left(\mathrm{w} \mathrm{v}^{-1}\right)\right)$ in ethylenediaminetetra-acetic acid (EDTA) solution when a confluency of $70-80 \%$ was reached.

Cell Seeding on the Micro-Objects: The concentration of micro-objects in medium after incubation was determined by counting the number of structures in $10 \mu \mathrm{L}$. Subsequently, a certain number of objects was added to the wells of the culture plates. Additionally, a specific number of cells was added within the same well. Mixing was applied by pipetting up and down shortly while adding medium up to the standard volume for that specific well.

Quantification of Aggregation Behavior: The number of structures incorporated within an aggregate was determined by counting the total number of structures in the well directly after seeding manually by image analysis. After 4 days of culture, the number of structures that was not incorporated within the aggregate was counted manually by image analysis. Circularity was calculated as a function of the perimeter $(P)$ and area $(A)$ of the aggregate measured by image analysis using the function 'measure' in Image). The outline of the aggregate, corresponding to the perimeter, was drawn manually.

$$
\text { Circularity }=\frac{4 \pi A}{p^{2}} \times 100 \%
$$

Viability Staining: To determine cell viability throughout the aggregates, a live/dead staining was performed. After washing the aggregates twice with PBS, they were incubated for $30 \mathrm{~min}$ with a $6 \mu \mathrm{M}$ ethidium homodimer (red fluorescent) $/ 1 \mu \mathrm{M}$ calcein (green fluorescent) mixture in PBS solution (LIVE/DEAD viability/cytotoxicity kit, Invitrogen/ Molecular Probes) at room temperature (RT). Prior to imaging, aggregates were washed with PBS three times. Images were taken with a fluorescence microscope (Nikon Eclipse E600 and Nikon DS-Filc camera) using a Nikon Texas Red/FITC filter set.

Histology: Samples were dehydrated in increasing concentrations of ethanol $\left(50,60,70,80,90,96\right.$ and $\left.100 \%\left(v v^{-1}\right)\right)$ for 30 min per step. Prior to embedding the samples into a two-component glycol methacrylate (GMA) (Merck) acrylic resin, the $100 \%$ ethanol was exchanged with $50 \%$ $\left(v v^{-1}\right)$ GMA-component $A$ in ethanol and incubated over night $(0 / n)$ at $4{ }^{\circ} \mathrm{C}$. Additionally, the samples were immersed in $100 \%$ GMA-A for $8 \mathrm{~h}$ at $4{ }^{\circ} \mathrm{C}$. The samples were transferred to a Teflon ${ }^{\circledR}$ mold and the two-component GMA was added and allowed to polymerize for $48 \mathrm{~h}$. Sections of $10 \mu \mathrm{m}$ thickness were obtained by cutting with a microtome (Microm HM355S, Thermo Scientific). Prior to staining, the sections were rehydrated in DI-water for $10 \mathrm{~min}$. For the hematoxilin and eosin staining, Gill's hematoxylin (Sigma-Aldrich) was applied for $30 \mathrm{~min}$. After rinsing $3 \mathrm{~min}$ with tab water and additionally $3 \mathrm{~min}$ in DI-water, samples were counterstained with eosin for $6 \mathrm{~min}$ and dehydrated in $100 \%$ ethanol. The samples were dehydrated with ethanol, coverslips were mounted and imaging was carried out using a Nikon Eclipse E600 with a Nikon DS-Filc camera.

Preparation and Filling of Microwell Arrays: Patterned chips from polydimethylsiloxane (PDMS) were placed in a 6-well plate (NUNC). A heated agarose solution ( $3 \%\left(w v^{-1}\right)$, UltraPure agarose, Invitrogen) was casted on each PDMS chip. The agarose was allowed to solidify at $4{ }^{\circ} \mathrm{C}$. Subsequently, the molds were removed from the obtained agarose chips. Cylindrical pieces were punched out of the agarose chips and placed in 12-well plates. To fill the cylindrical microwells, objects were added in small amounts until all the wells were completely covered with structures. Additionally, a certain amount of cells was added, and a short centrifugation after mixing promoted the cells and objects to settle in the microwells.

Statistical Analysis: All results were expressed as mean value and standard deviation (error bars). Statistical significance was tested by one-way analysis of variance (ANOVA) and Tukey's Multiple Comparison Test was carried out as post-hoc comparison using SPSS Statistics software (IBM). Statistical significance is indicated by $* * * *$ or $* * *$ corresponding to $p<0.05, p<0.01$ and $p<0.001$, respectively.

\section{Supporting Information}

Supporting Information is available from the Wiley Online Library or from the author.

\section{Acknowledgements}

The authors gratefully acknowledge the funding from the Netherlands Institute for Regenerative Medicine (NIRM) through the grant number FES0908. Authors declare that there is no conflict of interest. The authors would like to acknowledge Gerard Cadafalch Gazquez for assistance on the AFM analysis and Roy Visser for assistance in rheological tests.

Received: September 9, 2013

Revised: November 23, 2013

Published online: January 7, 2014

[1] E. C. Wu, S. G. Zhang, C. A. E. Hauser, Adv. Funct. Mater. 2012, 22, 456.

[2] a) J. Elisseeff, A. Ferran, S. Hwang, S. Varghese, Z. Zhang, Stem Cells and Development 2006, 15, 295; b) J. P. Vacanti, R. Langer, Lancet 1999, 354, Si32.

[3] a) L. A. Solchaga, E. Tognana, K. Penick, H. Baskaran, V. M. Goldberg, A. I. Caplan, J. F. Welter, Tissue Eng 2006, 12, 1851; b) B. S. Harrison, D. Eberli, S. J. Lee, A. Atala, J. J. Yoo, Biomaterials 2007, 28, 4628; c) H. Domaschke, M. Gelinsky, B. Burmeister, R. Fleig, T. Hanke, A. Reinstorf, W. Pompe, A. Rosen-Wolff, Tissue Eng 2006, 12, 949; d) G. Kumar, C. K. Tison, K. Chatterjee, P. S. Pine, J. H. McDaniel, M. L. Salit, M. F. Young, C. G. Simon Jr., Biomaterials 2011, 32, 9188.

[4] a) F. Causa, P. A. Netti, L. Ambrosio, Biomaterials 2007, 28, 5093; b) D. L. Elbert, Curr. Opin. Biotechnol. 2011, 22, 674.

[5] a) N. C. Rivron, J. Rouwkema, R. Truckenmuller, M. Karperien, J. De Boer, C. A. Van Blitterswijk, Biomaterials 2009, 30, 4851; b) J. W. Nichol, A. Khademhosseini, Soft Matter 2009, 5, 1312; c) J. S. Liu, Z. J. Gartner, Trends Cell Biol. 2012, 22, 683.

[6] a) J. M. Kelm, V. Djonov, L. M. Ittner, D. Fluri, W. Born, S. P. Hoerstrup, M. Fussenegger, Tissue Eng. 2006, 12, 2151; b) K. Jakab, C. Norotte, B. Damon, F. Marga, A. Neagu, C. L. Besch-Williford, A. Kachurin, K. H. Church, H. Park, V. Mironov, R. Markwald, G. Vunjak-Novakovic, G. Forgacs, Tissue Eng. 2008, 14, 413; c) K. Jakab, C. Norotte, F. Marga, K. Murphy, G. Vunjak-Novakovic, G. Forgacs, Biofabrication 2010, 2, 022001; d) P. R. Baraniak, T. C. McDevitt, Cell Tissue Res. 2012, 347, 701; e) F. Langenbach, C. Naujoks, R. Smeets, K. Berr, R. Depprich, 
N. Kubler, J. Handschel, Clin. Oral Invest. 2013, 17, 9; f) T. Masuda, N. Takei, T. Nakano, T. Anada, O. Suzuki, F. Arai, Biomed. Microdevices 2012, 14, 1085.

[7] a) F. Yanagawa, H. Kaji, Y. H. Jang, H. Bae, D. Yanan, J. Fukuda, H. Qi, A. Khademhosseini, J. Biomed. Mater. Res. 2011, 97, 93; b) P. Zorlutuna, N. Annabi, G. Camci-Unal, M. Nikkhah, J. M. Cha, J. W. Nichol, A. Manbachi, H. Bae, S. Chen, A. Khademhosseini, Adv. Mater. 2012, 24, 1782.

[8] M. B. Oliveira, J. F. Mano, Biotechnol. Prog. 2011.

[9] M. Radisic, J. Malda, E. Epping, W. L. Geng, R. Langer, G. Vunjak-Novakovic, Biotechnol. Bioengin. 2006, 93, 332.

[10] S. R. Van Tomme, G. Storm, W. E. Hennink, Int J Pharm 2008, 355,1 .

[11] a) M. Hennemeyer, F. Walther, S. Kerstan, K. Schurzinger, A. M. Gigler, R. W. Stark, Microelectron. Eng. 2008, 85, 1298 b) C. Hassler, T. Boretius, T. Stieglitz, J Polym. Sci. Pol. Phys. 2011, 49, 18; c) K. V. Nemani, K. L. Moodie, J. B. Brennick, A. Su, B. Gimi, Mater. Sci. Eng. C 2013, 33, 4453; d) G. Kotzar, M. Freas, P. Abel,
A. Fleischman, S. Roy, C. Zorman, J. M. Moran, J. Melzak, Biomaterials 2002, 23, 2737; e) B. Rubehn, S. B. Wolff, P. Tovote, A. Luthi, T. Stieglitz, Lab Chip 2013, 13, 579.

[12] J. L. Simonsen, C. Rosada, N. Serakinci, J. Justesen, K. Stenderup, S. I. S. Rattan, T. G. Jensen, M. Kassem, Nat. Biotechnol. 2002, 20, 592.

[13] H. Qi, M. Ghodousi, Y. Du, C. Grun, H. Bae, P. Yin, A. Khademhosseini, Nat. Commun. 2013, 4.

[14] a) P. R. Baraniak, M. T. Cooke, R. Saeed, M. A. Kinney, K. M. Fridley, T. C. McDevitt, J. Mech. Behav. Biomed. 2012, 11, 63; b) L. Preziosi, D. Ambrosi, C. Verdier, J. Theor. Biol 2010, 262, 35.

[15] H. Sekine, T. Shimizu, K. Sakaguchi, I. Dobashi, M. Wada, M. Yamato, E. Kobayashi, M. Umezu, T. Okano, Nat. Commun. 2013, 4.

[16] G. Eng, B. W. Lee, H. Parsa, C. D. Chin, J. Schneider, G. Linkov, S. K. Sia, G. Vunjak-Novakovic, Proc. Natl. Acad. Sci. USA 2013 $110,4551$.

[17] S. K. Both, A. J. C. Van der Muijsenberg, C. A. Van Blitterswijk, J. De Boer, J. D. De Bruijn, Tissue Eng. 2007, 13, 3. 